DOI 10.18551/rjoas.2019-11.19

\title{
THE ROLE OF SOCIAL CAPITAL FOR THE PERFORMANCE OF MSMES
}

\author{
Sinarwati Ni Kadek, Budhi Made Kembar Sri, Utama Made Suyana, Marhaeni A.A.I.N. \\ Faculty of Economics and Business, University of Udayana, Indonesia \\ *E-mail: kadeksinar20@gmail.com
}

\begin{abstract}
The objective of this article is to describe the review the of research finding on the role of social capital for the performance of MSMEs. An explanation of the role of social capital for the performance of MSMEs starts with the existence of MSMEs in Indonesia, the definition of social capital, the dimensions of social capital and the role of social capital for the lives of farmers, fishermen and craftsmen. It is concluded that social capital can increase the performance of MSMEs.
\end{abstract}

\section{KEY WORDS}

Social process, capital, performance, public service.

Micro, Small and Medium Enterprises (MSMEs) of Indonesia, are the main pillars of the economy. Micro-scale scale entities play a strategic role as people's safety nets in the face of crises and economic turbulence, so that the existence of reliable and strong MSMEs is the main capital of economic development, and becomes a bearing in facing global economic turmoil (Indonesian Bank, 2015).

MSMEs have a strategic role in national economic development, because in addition to playing a role in economic growth and absorption of labor, they also play a role in the distribution of development outcomes. MSMEs have proven to be more resilient in facing a crisis when several large periodic business sectors stagnate and even stop their activities (Amalia et al., 2017), given their role in the economy, the development of MSMEs becomes crucial. MSMEs act as the foundation of the Indonesian economy, which affects the economy. MSMEs rarely rely on funding from banks, so they are free from bad credit. Technology that is labor intensive and local resources, the products produced can be sold at low prices (Bismala and Handayani, 2014). MSMEs have special characteristics that distinguish them from large types of businesses, including the characteristics that distinguish micro, small and medium enterprises. The labor needed by small industries does not require high formal education, most of the labor needed by this industry is based on experience (learning by doing) which is related to historical factors (Sulistyastuti, 2004).

The development of MSMEs in Indonesia has increase after the global crisis. The growth in the number of MSMEs continues to increase with a considerable absorption of labor as presented in Table 1. The number of MSME units continues to increase from year to year. The increase from 2011 to 2012 was 2.4 percent. The same percentage increase occurred from 2012 to 2013. The percentage increase in a row from 2013 to 2017 was 1.8 percent, 1.98 percent, 1.65 percent and 5.17 percent. The average percentage increase in the number of MSME units for six years from 2011 to 2017 is 2.68 percent. Some researchers found that social capital plays a role in increasing the number of MSMEs.

Table 1 - The Development of MSMEs in Indonesia Period of 2011-2017

\begin{tabular}{ccccc}
\hline Year & $\begin{array}{c}\text { Number Of MSMEs } \\
\text { (unit) }\end{array}$ & $\begin{array}{c}\text { Number Of Employees } \\
\text { (person) }\end{array}$ & $\begin{array}{c}\text { Contribute Of MSMEs To DPB } \\
\text { (Billion Rp) }\end{array}$ & $\begin{array}{c}\text { Export Value Of MSMEs } \\
\text { (Billion Rp) }\end{array}$ \\
\hline 2011 & 55.206 .444 & 101.722 .458 & 1.369 .326 & $187.441,82$ \\
2012 & 56.534 .592 & 107.657 .509 & 1.451 .460 & $166.626,50$ \\
2013 & 57.895 .721 & 114.144 .082 & 1.536 .919 & $182.112,70$ \\
2014 & 58.943 .772 & 128.850 .942 & 1.670 .662 & $191.442,32$ \\
2015 & 60.106 .629 & 136.779 .510 & 1.794 .993 & $197.970,28$ \\
2016 & 61.100 .715 & 138.231 .124 & 1.800 .859 & 198.726 .512 \\
2017 & 64.201 .065 & 140.196 .503 & 1.998 .033 & 201.023 .110 \\
\hline
\end{tabular}

Source: Central Statistics Agency, 2018 
Concept of Social Capital. The concept of social capital was first put forward by Coleman (1988) who defined it as aspects of the structure of interpersonal relationships that enable them to create new values. Coleman distinguishes between social capital, physical capital and human capital. According to World Bank (2005), social capital is not as simple as just the sum of the institutions formed by society, but it is also an adhesive and reinforcement that unites them together. Unlike human capital, which emphasizes everything to be more referring to individual dimensions, namely the power and expertise possessed by an individual, social capital emphasizes the potential of groups and patterns of relationships between individuals in a group and between groups with space for attention to dimensions social capital such as social networks, norms, values, and beliefs among people born to group members and become group norms.

Social capital includes institutions, relationships, attitudes and values that direct and mobilize interactions between people and contribute to social and economic development. Social capital can be a stimulant capital owned by a population to unlock other capital potentials such as human resources, physical resources, natural resources and financial resources (La Ola, 2011).

According to Lawang (2004), social capital refers to all the strengths of community social forces that are constructed by individuals or groups by referring to social structures which according to their judgment can achieve individual and/or group goals efficiently and effectively with other capital. The nature of social capital is the social relationship that is interwoven in the daily lives of citizens. Social relations reflect the results of social interactions in a relatively long time so as to produce networks, patterns of cooperation, social exchange, mutual trust, including values and norms that underlie social relations (Ibrahim, 2006).

Social capital can be an identification to measure economic performance. At the macro level the indicators are the emergence of trusts, civic norms and aspects of social capital as a basis for economic development (Knack and Keefer, 1997). The dimensions of social capital describe everything that makes communities allied to achieve common goals on the basis of togetherness, and in them are bound by values and norms that grow and are obeyed (Dasgupta and Serageldin, 1999).

Social capital has six dimensions, namely: 1) total membership; 2) the level of diversity of group members/organizations; 3) intensity of meetings; 4) level of decision making; 5) the level of contribution (money and energy); and 6) community orientation (Grootaert, 1998). Krishna and Uphoff (1999) distinguish social capital into two complementary dimensions, namely structural dimensions and cognitive dimensions. Both of these dimensions have general elements that encourage behavior to collaborate profitably.

Winter (2000) identifies social capital into six dimensions, namely: 1) habits (type of agreement: formal and informal); 2) shared goals (between institutions respect for respect); 3 ) relationships in the relationship of "bridging" (trust and reciprocity) mutually build together; 4) social capital as an intermediary (trust can build a system of closeness between individuals); 5) the intensity of the relationship (the intensity of the relationship between individuals is wealth and multiple benefits in society); and 6) social location (establishing kinship relations) can build social capital resources. Haddad and Maluccio (2000) divide social capital into three dimensions, namely: 1) the level of household participation in the group; 2) group functions for households; and 3) the level of trust of households in the group.

Several studies on social capital in relation to various collective activities have been carried out. Ohama's (2001) research in Philippine Central Luzon found that collective work did not only alleviate the farming community from the poverty trap, but also succeeded in creating a social capital in the form of developing the people's organization "Ugnayang Magsasakang San Siomon (UMSS)". Several other cases in various Latin American and Caribbean countries, such as El Salvador, Jamaica, Venezuela, Columbia, Argentina, and Bolivia, show a correlation of social capital with a reduction in the number of poor people through a program named "Government, Business, and Civic Partnerships for Poverty Reduction (Fiszbein and Lowden, 1999). 
Mackie's research (1998) concludes that the key to success of Chinese businessmen at the global level is caused by two factors, namely: (1) international trust in xinyong (trust) which serves as an adhesive that binds trade transactions; and (2) guanxi (personal relations) as a tool to reduce transaction costs in business carried out in various situations where legal protection for contract implementation is often unreliable. Xinyong and guanxi are dimensions of social capital, that is, the use of social capital is one of the keys to the success of Chinese businessmen on a global level.

Amin (2016) examines the role of social capital in poverty alleviation in the Betet SubDistrict Pesantren District in Kediri Regency, finding that the characteristics of the social capital of the respondents included trust, networks, established values and norms, participation and pro-active actions. The existence of social capital contributes positively to the existence of poverty alleviation programs that emphasize community participation in various activities. Pranadji (2006) examined the strengthening of social capital for the empowerment of rural communities in the management of dry land agrosystems. Wafa (2003), in his research looked at how networks and norms as elements of social capital built in farmer groups are beneficial for increasing productivity of farmer groups "Mardi Utomo", by sharing information about the production process and cooperating in post-harvest sales to strengthen the position of members of farmer groups in dealing with buyers of agricultural products. Lubis (2002), highlights how the work of the element of social capital namely trust in an ethnic Chinese population, finds that trust among member members is a strong glue for better cooperation.

Several studies which examined the influence of the importance of social capital if developed in society, were carried out by Brata (2004) in Yogyakarta who found that social capital in the form of networks was beneficial in obtaining informal loans or assistance, when formal government assistance was very limited. This situation is in line with what was found by Bastelaer (2000), that the poorest members of society who do not have access to microcredit facilities, make social networks an important element to fulfill their capital. Badaruddin's (2003) study of the fishing community found that one of the factors causing the difficulty of traditional fishing communities and labor fishermen out of the poverty trap was the low or undeveloped social capital in the community. Hasbullah (2006) added, the basic problem that needs to be studied about the failure of programs and policies related to welfare so far, is careless in identifying the factors that determine the social capital of the community. Puspito (2016) who examined social capital in the Kuantan Brotherhood Society found that the existence of social capital in the community is one of the main components in mobilizing togetherness, solidarity and mutual trust and mutual benefit to achieve common goals.

Other studies include Pranadji (2006) on strengthening social capital for empowering rural communities in the management of dryland agroecosystems, Cahyono and Adhiatma (2012) on the role of social capital in improving the welfare of tobacco farmers in Wonosobo Regency. Witjaksono (2010) conducted a study of social capital in the dynamics of the development of the Waru Sidoarjo metal industry center, finding that in the economic context the development of social capital is a pillar of other forms of capital (physical, financial and human capital).

Thobias, et al. (2013) examined the effect of social capital on entrepreneurial behavior (a study of micro, small and medium enterprises in Kabaruan District, Talaud Islands Regency). Tohani, et al. (2015) conducted a study on the utilization of social capital in community entrepreneurship education: willingness in the vocational village education program concluded that the utilization of social capital could be carried out by the community. Social capital that is built and utilized by entrepreneurs (target groups) is manifested in productive relations with other individuals or organizations either because of friendship, brotherhood, business interests and regulations.

Sanatana et al. (2018) found that social capital has a direct and positive effect on the employment opportunities of farmers who are members of the simantri group in Bali, which means that better social capital from farmers who are members of the simantri group in Bali Province will provide higher employment opportunities for farmers are members of the simantri group. High social capital is demonstrated through the strong relationship between 
farmers and farmers still maintaining local wisdom in the social life of farmers. High employment opportunities are indicated by the giving of work in the form of giving responsibility for the maintenance of a cow in a combination of farmer groups (gabungan kelompok tani: gapoktan).

Social Capital and Sustainability of MSMEs. The development of MSMEs in Indonesia must be strategic and have a long-term impact because this refers to the growth of employment and improvement of regional and national economies (Nurhajatie, 2009). One factor that can improve the performance of MSMEs is social capital (Prestutti et al, 2016, Meflinda et al, 2018, Habersetzer et al, 2018).

Muslikah, et al (2018) examined the influence of entrepreneurial competencies, entrepreneurial strategies and social capital on sustainable competitive advantage with business performance (entrepreneurs) as intervening variables, finding that entrepreneurial strategies and social capital have an influence on the performance of entrepreneurs with the concept of competitive advantage as an intervening variable. Social capital is closely related to the relationships between individuals, norms, and beliefs that facilitate coordination and mutually beneficial cooperation. The components of social capital should be utilized maximally by individual MSME actors, for example social networks are used by individuals to gain market, knowledge, cooperation and assistance with tools, capital and others, while trust is used by individuals to build commitment with other parties in order to maintain

cooperation already established.

Yuliarmi, et al (2015), examined the empowerment of the household craft industry for poverty alleviation in Bali Province (in terms of aspects of social capital and the role of customary institutions) found that social capital had no significant effect on the empowerment of SCE. Social capital is very important for craftsmen, but to be able to be empowered in conducting business activities is still very much in need of the role of other variables. The positive relationship between social capital and the empowerment of SCE means that there is a supportive relationship between perceptions of social capital indicators and perceptions of the existence of SCE.

Prasetyo and Harjanti (2013) examined the social capital of micro and small entrepreneurs (MSEs) in the informal sector and their relationship with business performance in the East Java region found that the dimensions of social capital were financial support, network support and moral support received by respondents in this case entrepreneurs small micro enterprises in the informal sector become one of the important factors in the sustainability of the MSEs being run. The social capital of SMEs owners in the informal sector in the East Java region who are the respondents of the study has a relationship with business performance on several indicators including: education level indicators with customer targeting, and pricing, indicators of parental financial support, gender, and promotions carried out, as well as current products and discounts.

The role of social capital in the progress of business organizations is evidenced by the research findings, including Sozbilir (2018), finding that the interaction between elements of social capital can encourage creativity and efficiency of companies in Turkey. This finding supports previous empirical findings which state that social capital is an important organizational phenomenon affecting several dynamics and outcomes including corporate creativity. The findings of the role of social capital on the success of micro enterprises are published by Aldecua, et all (2017), who conducted research on the local wine industry in Catalonia. Research with the case study design found that bonding and bridging as dimensions of social capital dimensions strengthened the interplay between wine entrepreneurs so as to increase innovation in production among wine entrepreneurs. The findings of Aldecua, et all (2017) support previous research conducted by Galbreath et al (2016) which states that social capital has been continuously related to competence and innovation of regional wine production.

Social capital contributing to the progress of MSMEs was also investigated in Thailand. Phuangrod, et all (2017) found that networks that are built between small and medium entrepreneurs can improve business performance. Net working is a network of social interactions and personal relationships that are contained in human capital. The network 
forms social capital among entrepreneurs. The network helps drive business growth and business capabilities to survive small and medium entrepreneurs in the southern part of the Province of Thailand. Net working also results in entrepreneurs getting information earlier than competitors, so the company has an advantage in competing.

\section{CONCLUSION}

MSMEs are the backbone of the economy in Indonesia. The role of MSMEs in the economy has been found in several countries. The role shown by MSMEs includes absorbing labor and contributing to foreign exchange for the country. The government has given attention to MSMEs in order to maintain the sustainability of MSMEs and encourage their growth. Some research on factors that influence the development and performance of MSMEs found that social capital is one of the drivers of improving MSME performance.

Social capital is a combination of norms, mutual cooperation attitudes and networks which are intangible assets which are actual and potential resources. The existence of social capital in an institution was found to play a role in increasing the quantity and quality of output from the institution. Several studies on the role of social capital for improving institutional performance are carried out in various countries including Indonesia, in various sectors including the agriculture, forestry and business sectors. The findings of the researchers stated that networks and norms were able to alleviate the poverty of farmers, in the field of business social capital was found to be able to increase entrepreneurial spirit.

The importance of social capital for MSMEs is a research finding that states that there is a positive relationship between social capital and the empowerment of SCEs, the dimensions of social capital namely financial support, network support, and moral support received by small micro entrepreneurs in the informal sector become an important factor in the sustainability of MSEs run. Researchers from Turkey, Thailand, China and Catalonia also found that network bonding and bridging were able to enhance the creativity and innovation of products of small and medium entrepreneurs.

\section{REFERENCES}

1. Aldecua Maria Jose Fernandez, Vailant Yancy, Lafuente Esteban, Gomez Jargo Moreno. 2017. The Renaissance Of A Local Wine Industry: The Relevance Of Social Capital For Businness Inovation In DOQ El Priorat Catalonia. International Journal. Elsevier. Available online at www.sciencedirect.com.

2. Amalia, Alfi; Hidayat Wahyu and Budiatmo, Agung. 2017. Analisis Strategi Pengembangan Usaha Pada UKM Batik Semarangan Di Kota Semarang. Jurnal IImu Administrasi and Bisnis.

3. Amin, Taufik Al.2016. Peranan Modal Sosial Dalam Penanggulangan Kemiskinan Di Kelurahan Betet Kecamamatan Pesantren Kota Kediri. Jurnal. Realita. Vol. 14. No. 1 Januari 2016. P 49-64.

4. Badaruddin, 2003, Modal Sosial and Reduksi Kemiskinan Nelayan di Propinsi Sumatera Utara, Laporan Penelitian Hibah Bersaing Perguruan Tinggi, Dirjen Dikti., Jakarta.

5. Bank Indonesia. 2015. Kajian Mengenai Rumusan Standar Minimum Laporan Keuangan and Business Plan untuk UMKM- Persiapan Bank Indonesia Dalam Menghadapi Masyarakat Ekonomi ASEAN 2015. Jakarta.

6. Bastelaer, Van T., 2000, Does Social Capital Facility the Poor's Access to Credit? A Review on the Microeconomic Literature, Social Capital Initiative Working Paper No. 8, The World Bank, Washington, D.C.

7. Bismala, Lila and Handayani, Susi. 2014. Model Manajemen UMKM Berbasis Analisis SWOT. Naskah Lengkap Seminar Nasional PB3I ITM. Universitas Muhamadyah Sumatera Utara.

8. Bourdieu, Pierre, 1980, The Production Of Belief: Contribution To An Economy Of Symbolic Goods, Journal Media, Culture and Society Vol. (3). 
9. Brata, Aloysius G., 2004, Nilai Ekonomis Modal Sosial pada Sektor Informal Perkotaan, Makalah Lembaga Penelitian Universitas Atma Jaya, Jakarta.

10. Cahyono, Budhi and Ardian Adhiatma, 2012, Peran Modal Sosial dalam Peningkatan Kesejahteraan Masyarakat Petani Tembakau di Kabupaten Wonosobo, Naskah Lengkap Conference In Business, Accounting and Management (CBAM) Vol.1 No.1.

11. Coleman, James S. 1988. Social Theory, Social Research, and a Theory of Action. The American Journal of Sociology, Vol 91 No. 6, May: 1309-1335.

12. Dasgupta, Partha and Ismail Serageldin, 1999, Social Capital: A Multifaceted Perspective, Paper, The World Bank, Washington.

13. Fiszbein, Ariel, and Pamela Lowden, 1999, Working Together For A Change: Government, Civic, And Business Partnerships For Poverty Reduction In Latin America And The Caribbean, Paper World Bank, Washington.

14. Grootaert, Christian. 1998. Social Capital: The Missing Link? Social Capital Initiative, Working Paper No.3, World Bank.

15. Haberzetser Antoine, Sandra Greser Bucher, Ron Boschma, Heike Mayer. 2018. Enterprise-related social capital as a driver of firm growth in the periphery?. Journal Of Rural Studies. Journal homepage. www.elsevier.com/locate/jrurstud.

16. Haddad, Lawrance and John Maluccio. 2000. Social Capital and Household Well-being in South Africa: Patways of Influence. Working Paper Prepared For Presentation At The Study Of African Economies. International Food Policy Research Institute. New York.

17. Knack, S., and Keefer P. 1997. Does Social Capital Have An Economic Payoff? A CrossCountry Investigation. The Quarterly Journal of Economic.

18. Krishna, Anirudh and Norman Uphoff. 1999. Mapping and Measuring Social Capital: A Conceptual and Empirical Study of Collective Action for Conserving and Developing Watersheds in Rajasthan, India, Social Capital Initiative Working Paper No. 13. World Bank.

19. La Ola, H. Taane, 2011, Modal Sosial and Pengaruhnya Terhadap Perilaku Ekonomi and Kesejahteraan Petani Jambu Mete, Disertasi Pascasarjana Universitas Hasanudin, Makasar.

20. Lawang, Robert M.Z., 2004, Kapital Sosial Dalam Perspektif Sosiologik (suatu Pengantar), Fisip UI Press, Jakarta.

21. Lubis, Zulkifli, 2002, Resistensi, Persistensi and Modal Transmisi Modal Sosial Dalam Pengelolaan Sumber Daya Milik Bersama, Kajian Atropologi Terhadap Lubuk Larangan di Sumatra Utara, Jurnal LIPI/RISTEK, Jakarta.

22. Mackie,J., 1998, Chinese Business Organizations, in L. Pan (ed.), The Encyclopedia of the Chinese Overseas, Archipelago Press, Singapore.

23. Meflinda Astuti, Mahyami Mahyami, Indrayani Henni, Wulandari Hesti. 2018. The effect of social capital and knowledge sharing to the small medium enterprises perfomance and sustanaibility strategies. International Journal Of Low and Management. Emerald Insight.

24. Muslikah, Haryono and Harini. 2018. Pengaruh Kompetensi Entrepreneurial, Strategi Kewirausahaan and Modal Sosial Terhadap Keunggulan Kompetitif Berkelanjutan Dengan Kinerja Usaha Sebagai Variabel Intervening Studi Kasus UKM Mebel Di Desa Kembang Kabupaten Jepara. Makalah Mahasiswa and Dosen Jurusan Manajemen Fakultas Ekonomika and Bisnis Universitas Pandanaran Semarang.

25. Ohama, Y., 2001, Conseptual Framework of Participatory Local Social Development (PLSD), Paper PSLD Theories and Practices, JICA, Nagoya.

26. Phuangrod Kritsadee, Lerkiatbundit Sanguan, Aujiraponpan Somnuk. 2017. Factor Affecting Innotitivness Of Small Medium Enterprisee In The Five Southern Border Provinces. International Journal. Kasestartt of Journal Social Science 38 pp (204-211).

27. Pranadji, Tri., 2007, Model Pemberdayaan Masyarakat Perdesaan untuk Pengelolaan Agroekosistem Lahan Kering (Studi Penguatan Modal Sosial dalam Desa-desa Hulu DAS Ex Proyek Bangun Desa, Kabupaten Gunung Kidul and Ex Proyek Pertanian Lahan Kering, Kabupaten Boyolali, Jurnal Agro Ekonomi Vol. 24 No.2. 
28. Prasetyo Tommy and Harjanti Dyah 2013. Modal Sosial Pengusaha Mikro and Kecil Sektor Informal and Hubungannya Dengan Kinerja Bisnis di Wilayah Jawa Timur. Jurnal Agora Vol. 1 No. 3.

29. Prestutti Manuela, Boari Christina, Fratocchi Luciano. 2018. The Evolution Of Inter Organisational Social Capital With Foreign Customer: Its direct and Interactive Effect On SMEs Foreign Perfomance. Journal Of Word Business. www.elsevier.com/locate/jwb.

30. Puspito, Hendro. 2016. Studi Sosiologis Tentang Modal Sosial Pada Paguyuban Persaudaraan Jawa Kuantan Singingi Perjasing. Jurnal JOM FISIP. Vo. 3. No. 1. P 1-15

31. Sanatana, I Made Mahadi; Sudibya I Ketut; Mahaendrayasa Nyoman; Murjana Yasa. 2018. The Role of Social Capital Towards Famers Job Opportunity in Simantri Group in Bali Province. International Journal Of Social Scince and Humanities Research. Vol. 6, Issue 1 pp(488). ISSN: 2348-3156.

32. Sozbilir Fikret. 2018. The Interaction Betwen Social Capital, Creativity and Efficiency Organizations. International Journal. Elsevier. Thinking Skills and Creativiy. Pp (92-100).

33. Sulistyastuti. Dyah Ratih 2004. 'Dinamika Usaha Kecil and Menengah (UKM): Analisis Konsentrasi Regional UKM di Indonesia 1999-2001', Jurnal Ekonomi Pembangunan, Volume 9, Nomor 2 Desember 2004, Halaman 143-164, http://journal.uii.ac.id/index.php/JEP/article/view/617/543 diunduh tanggal 26 Juni 2013.

34. Thobias, Erwin, A.K. Tungka, and J.J. Rogahang, 2013, Pengaruh Modal Sosial Terhadap Perilaku Kewirausahaan (Suatu Studi Pada Pelaku Usaha Mikro Kecil Menengah Di Kecamatan Kabaruan Kabupaten Kepulauan Talaud), Jurnal Acta Diurna, April 2013.

35. Tohani, Entoh; Sumarno; Suryono, Yoyon. 2015. Pendayagunaan Modal Sosial Dalam Pendidikan Kewirausahaan Masyarakat: Studi Pada Program Pendidikan Desa Vokasi. Jurnal Pembangunan Pendidikan: Fondasi and aplikasi p-ISSN:2356-1807 e ISSN:25021648.

36. Wafa, Ali., 2003, Urgensi Keberadaan Social Capital dalam Kelompok-kelompok Sosial. Masyarakat, Jurnal FISIP Universitas Indonesia No.12.

37. Witjaksono, Wit. 2010. Modal Sosial Dalam Dinamika Perkembangan Sentra Industri Logam waru Sidoarjo. Jurnal Ekonomi Pembangunan. Volume 11. Nomor 2. HIm 266290.

38. Winter, Ian. 2000. Towards a theorised understanding of family life and Social Capital. Working Paper No. 21. Australian Institute of Family Studies. Australia.

39. World Bank, 2005, The Initiative on Defining, Monitoring and Measuring Social Capital Text of Proposal Approved for Funding, Social Capital Initiative Working Paper No.2, The World Bank, Social Development Family, Environmentally and Socially Sustainable Development network.

40. Yuliarmi, Ni Nyoman, Marhaeni AAAIN, Saskara IAN. 2015. Keberdayaan Industri Kerajinan Rumah Tangga Untuk Pengentasan Kemiskinan di Provinsi Bali (Ditinjau dari Aspek Modal Sosial and Peran Lembaga Adat). Jurnal Piramida.Vol. IX. No. I hlm 34-43. ISSN:1907-3475. 